International Journal of English Literature and Social Sciences
Vol-6, Issue-2; Mar-Apr, 2021

\title{
The Frankenstein Paradigm: More than human, less than
} nothing

\author{
Paulo Alexandre e Castro
}

Instituto de Estudos Filosóficos, Universidade de Coimbra, Portugal

Received: 20 Dec 2020; Received in revised form: 03 Feb 2021; Accepted: 25 Feb 2021; Available online: 07 Mar 2021

(C2021 The Author(s). Published by AI Publication. This is an open access article under the CC BY license

(https://creativecommons.org/licenses/by/4.0/).

\begin{abstract}
This paper begins with the examination of some premises of Mary Shelley's novel, Frankenstein or the Modern Prometheus, and briefly revisits some of the concepts or ideas that she had adapted and that will allow to determine the premises that characterize what we named as Frankenstein Paradigm. Such a paradigm, as we suggested, allows us to perceive, on the one hand, the avant-garde vision of Mary Shelley about human condition (regardless of literary immersion in gothic subjects), and on the other hand, the complexity of themes that would mark what is termed by post-human, that we will give some examples whether in contemporary art or in the framework of figures and representations of daily life (some illustrations on movies will be given). In this regard, we will notice the prosthetic transformations that have already occurred and, therefore, to verify the practical application of the premises contained in the Frankenstein paradigm. Next, it is necessary to carry out a reflection on the ethical and social implications posed by post-humanism as the well-known paradox of the ship of Theseus (which, as we all know, illustrates the problem of identity).
\end{abstract}

Keywords_Frankenstein, Post-humanism, Mary Shelley, Human nature.

\section{INTRODUCTION TO MARY SHELLEY'S FRANKENSTEIN}

Mary Shelley writes in the preface of Frankenstein or Modern Prometheus, from the revised edition (1831), that the novel

affords a point of view to the imagination for the delineating of human passions more comprehensive and commanding than any which the ordinary relations of existing events can yield. I have thus endeavoured to preserve the truth of the elementary principles of human nature, while I have not scrupled to innovate upon their combinations». (Shelley, 1869, p. 5).

In these confessional words of the writer, one feels the echo of his concern to put the authenticity (the essence) of human nature in the novel. What is noteworthy is not only the explicit reference to the possible combinations of these principles of human nature, but what may result from those combinations, that is, what is implied when man dares to make such combinations. When Shelley refers that she has "no scruples to innovate", she is precisely playing the divine role of Prometheus, meaning, she is actually challenging, like his character Victor Frankenstein, the natural course of events, whether in science and technology or in literature.

The theme about technology and their own evolution, and mostly, what could be done with it, was a topic at the intellectual conversations, among Mary Shelley and her friends. It is known that in 1816 Mary Shelley (she has only 19 years old) went to spend the summer with her future husband, Percy Bysshe Shelley, on the edge of Lake Geneva or Leman, where was also the friend and writer Lord Byron with which they had several discussions on this topic, since they were forced to be confined for several days because of the abnormal hostile climate for the time and place. Mary Shelley reports in Frankenstein's "Preface" that in the meeting at Lake Leman in Switzerland, one of these conversations was about various philosophical doctrines and they discussed 
among others, the nature of the principle of life, and whether there was any probability of its ever being discovered and communicated. They talked of the experiments od dr. Darwin (I speak not of what the Doctor really did, or said he did, but, as more to my purpose, of what was then spoken of as having been done by him), who preserved a piece of vermicelli in a glass cage, till by some extraordinary means it began to move with voluntary motion. Not thus, after all, would life be given. Perhaps a corpse would be re-animated; galvanism had given token of such things; perhaps the component parts of a creature might be manufactured, brought together, $n$ endued with vital warmth (Shelley 1869, p.11)

The three and one other guest, John Polidori, also a writer, spent their time reading to each other horror stories, particularly German ghost stories, and Lord Byron proposed that the four should write a ghost story. Mary Shelley was fascinated with all the conversations and discussions among them and she wants to write something that can merge these various themes, that can make different themes converge, from the old questioning of human condition and nature to the potentialities of modern technology. The novel becomes the perfect terrain to explore this possibility in a unique way: if technology allows Frankenstein to bring a creature to life, it is his questioning (the philosophical challenge) that gives it sustainability.

There are several important details in the novel, but one of the things that makes Mary Shelley's novel interesting and different is that this sort of questioning will also spring from the (humanized) creature and it is no coincidence that she puts the creature - when she isolates herself after the failure of her attempts to interact with humans -, observing the life of a small peasant family and contacting with literature. The creature learns to speak and to read (contrary to movies where the creature only grunts). The selected books are also interesting in these details: Plutarch's Parallel Lives, John Milton's Lost Paradise, and Johann Wolfgang von Goethe's The Sorrows of Young Werther.

If the first one (which is a series of 48 Greek and Roman biographies of famous men) gives him the dimension of human ambition, its successes and failures, and therefore of human nature, Lost paradise's poems provide him with a mystical and religious view of guilt, penitence, sin, and how the divine and human spheres always converge on suffering (such as the passionate relationship of Prometheus with humans and not so much with the gods). The last one, the Goethe's The Sorrows of Young Werther, which talks about Werther, a young and sensitive artist living in the fictional village of Wahlheim, admiring the simple life of peasants, before falling in love with charlotte, an unrequited love, it will provide him with that kind of passionate look at the peasants' lives and this might also explain the attempts to contact with them. At the same time, this book may also have suggested him the need for a mate -, which can be the explanation for the contact with his creator Frankenstein to create a female creature for him.

\section{GOTHIC FICTION: BETWEEN HUMAN AND TECHNOLOGY}

From just these small details we can see that the creature is humanized, he is not a zombie or an automaton; in fact, as Mary Shelley characterized him, the monster seems to be (somehow) superior to man both physically and intellectually. Maybe he is more than human, but less than nothing, meaning that, for instance, the irony of Shelley in giving an image of a monster that reacts as a child when threatened (full of sensibility) but at the same time he has a superhuman strength (of course this image as nothing to do to what with Nietzsche's meant with his Übermensch figure - the connection to be established is the enhancement of human species). What is at stake here is something that happens often and has been known for a long time, at least since Plato: the confusion that has been established between the domains of aesthetics and those of ethics or moral: the ugliness of the monster is confused with bad, with brutality (in the same way that beautiful is good, is kind); skipping from one domain to another without perceiving the full consequences.

For some of the reasons described above, the novel by Mary Shelley, Frankenstein or Modern Prometheus, should be understood as one of the major works on Gothic fiction. Note that it was not said Gothic literature but Gothic fiction. We are aware that this statement is very debatable, since it is legitimate to insert this novel in the genre of Gothic literature. However, we would like to maintain the affirmation of Gothic fiction. We want to, because, in the first place, it is not clear that the novel has all the characteristics that the genre of Gothic forces (for instance like the medieval scenario). Secondly, because it is believed that the author creates a new genre that would generate and influence a stream of ideas in the next century, precisely called science fiction. Thirdly, because there are elements of the romanticism movement that leads us to consider the hypothesis that it is a hybrid genre in its essence. And this last point is important: it is not only the psychology of terror felt (with feelings of apprehension, fear, madness), or the use of supernatural imagery, held mainly by the "creature", "monster", but is also a genre that provides an imaginative and speculative background 
for the advances of science and to their consequences, for the consequences of man's ambition, for playing God, and that is reflected in the title, Frankenstein or Modern Prometheus.

Like the Greek titan Prometheus, also Frankenstein was committed with the adventure of giving life, with the adventure of creating life, and in both cases they both suffered for their creations. Mary Shelley was clearly aware of this. Anne K. Mellor said that Frankenstein's quest is the conquest of death itself, which is the same desire that Frankenstein expressed by giving animation upon lifeless material (Mellor, 1988). This is an interesting point because we had seen this before, namely in Ovid's Metamorphoses, when talking about the myth of Prometheus, also men were made from clay and, of course, in the bible as it is known.

\section{INTRODUCING FRANKENSTEIN PARADIGM: LITERATURE AND CINEMA}

This hybrid genre is, in fact, one of the main reasons that give birth to what we call the "Frankenstein paradigm". And it is easy to see why: it is from here that the thought about the boundaries of the human begins to draw, which in another sense is equivalent to say that the post-human is beginning to be sketched, not only as a mere overcoming of the human as happened in the historical Renaissance humanism (that placed man at the centre of the universe and above all other species), but as an overcoming of humanity through scientific and technological domination.

This paradigm that Mary Shelley gave us through Frankenstein is the basis from which will emerge extraordinary works such as The Strange Case of Dr Jekyll and Mr Hyde (1886) by Robert Louis Stevenson, Dracula (1897) by Bram Stoker, The Picture of Dorian Gray (1890) by Oscar Wilde, among many others. Certainly, a closer reader will ask immediately how Bram Stoker or Oscar Wilde fits into the post human question referred above. It could be answered at first that these authors were influenced by the work of Mary Shelley, but in fact, it is not only that. There are elements in this paradigm that allow us to understand its scope. For instance, the human condition and human nature are exposed in an unavoidable way. There seems to be always some unorthodox experiment that leads to a specific purpose. There is always a very sapient creature, either because it has transcended the boundaries of the human or because it was created from the human, and here ambitions and dreams go unrestrained. The use of knowledge or wisdom for a specific end and the metaphorical use of the double are also to be considered. Also, an unnatural or unexpected event that brings to the beholder/reader (from the point of view of aesthetical experience) fear, disappointment or some other strange feelings about it.

These characteristics of the Frankenstein paradigm are even clear in movies. In fact, the question about a possible post-human condition which often mixes with the purposes of transhumanism (that is, the transformation of human condition by providing sophisticated technologies that can enhance intellectual and physiological performance), are now available in contemporary art. Not only films and books but in art in general, as in sculpture, dance, digital art and media art and so many others manifestations.

What Frankenstein`s novel introduced was far from being just another work of literature; it was the concepts, the way of putting in question the essence of human nature and the fragility on the human condition and their creations. In fact, in our society we see different myths that borne from Frankenstein`s paradigm. Through different forms of media, the influence and relevance of Frankenstein paradigm (creator and creature) is everywhere: from the first horror movies (in the early $20^{\text {th }}$ century) to the science fiction novels and philosophical and ethical essays, there are signs of several models and myths. According to The Illustrated Frankenstein Movie Guide, there are have been more than four hundred movies influenced by Frankenstein and dozens of adaptations (Jones, 1994). Note for instance that there were the 1931 success Frankenstein, in 1935, The Bride of Frankenstein, in 1939, Son of Frankenstein, in 1942 The Ghost of Frankenstein in 1943 Frankenstein meets the Wolfman, in 1957 The Curse of Frankenstein (and many others) all the way to 1994 Mary Shelley's Frankenstein. Note how the aesthetics initiated with the first ones - let us call the Karloff's aesthetics -, will influence for instance the series (1964-1966) and Tim Burton`s Frankenweenie. But the scope is larger: the post-humanism`s ideas are reflected in movies such as Ex Machina or I Robot.

All of these movies are also illustrations of the struggle between man and his ambitions, between creator and creation, between the acceptance of the human condition and the desire of immortality. In this sense, what is uncanny for us to consider about the novel Frankenstein is that it represents much of what we are or are going to be: dreamy creatures, ambitious and adventurous creatures, wandering creatures in search of comfort. Of course, we can look at these questions in another way: our human inability to accept the difference (Hitchcock, 2010) but that is another subject and requires a different approach (and also a different place). 


\section{MODERN FRANKENSTEINS AT THE BORDER OF NOTHINGNESS}

Unfortunately, we seem to find consolation in our age of post-culture and post-truth, in the banality of material goods (with all the problems associated with that). We are also transforming creatures, creatures that undergo prosthetic. Everything is being designed so that we are like modern Prometheus. In this sense, everything around us is being assimilated as if it were prosthesis. From the prostheses implemented in the biological body transformations (from bone prosthesis to brain chips), from smartphone to the GPS, from the algorithms that control our life to our continued adventure in the world of biotechnology and artificial intelligence, everything becomes part of us. This is ultimately the materialization of the Frankenstein paradigm, by making our nature and condition more than questionable, a source of ambition, a horizon of indecipherable meaning.

Now what is this transformed nature after all but the questioning of our identity? We are already in deeply transformation; a transmutation of our own essence through the rapid development of technology that reaches all areas of our daily life. Our physical and mental consistency (integrity) is no longer a parameter for our identity. Let us call the discussion the paradox of the Theseus`s ship, in order to perceive the ethical and philosophical implications (since sociological seem very clear already) of the creatures in transformation.

As is known, the paradox arises from the history of the ship that led Theseus (and other young boys) to be sacrificed to the Minotaur. The ship with which Theseus and the young men of Athens returned (from Crete) were not the same ship with which they had departed, since they were removing the old parts that rotted and placed new parts. The question is whether it can be said that the returning ship is the same ship that left, if it is the ship of thesis. The question is not only whether "A = B?" but what is B's identity? Putting the question according to frame of our paper, two or three questions arise immediately: 1) what does it mean to be like Frankenstein? 2) What does it mean to be a creature like the creation of Victor Frankenstein? What does it mean to be like a Theseus ship`s creature? Or the fundamental question, what is the purpose of life?

\section{CONCLUSION}

For the first question, it is important to remember that when one asks how it is to be like Frankenstein, it is not a matter of asking what it is like to be the monster or creature - which popular culture associated with the name Frankenstein - but what it is like to be like Frankenstein, the young scientist who brought the monster to life. That is not an easy question, after all, the qualia (conscious experience of being unique, the so-called experience of what is like to be something popularized by the philosopher Thomas Nagel) does not allow to say it. But, from a more literary/metaphoric point of view, one could answer that, to be like Victor Frankenstein is to be human, with all the merits and flaws that characterize human nature. For the second question, it could be said that it is the human condition in its ambitious trajectory to materialize the deep desire to be another. And for the third question, the purpose of life, we quote the last words of Victor when speaking to Walton, to search "happiness in tranquillity and avoid ambition". This ironic answer of Victor gives us the conclusion and reinforce what is the truly meaning of the Frankenstein Paradigm: that being more than human, can be after all, less than nothing.

\section{REFERENCES}

[1] Aeschylus (1926). Prometheus Bound. Greek Tragedy C5th B.C. (Trans Herbert Smith Weir). Loeb Classical Library (Vol. 145 \& 146). Cambridge: Harvard University Press. Retrieved from: http://www.theoi.com/Text/AeschylusPrometheus.html"

[2] Aeschylus, Fragment 204, Retrieved from: http://www.theoi.com/Text/AeschylusFragments3.html

[3] Castro, Paulo Alexandre e (2017), Acerca do Indizível. Sobre a linguagem e outras coisas em Wittgenstein. Porto: Fénix Editores.

[4] Castro, Paulo Alexandre e (2006), Metafísica da Imaginação - Estudos sobre a Consciência Irrealizante a partir de Sartre. Lisboa: BonD-Quimera.

[5] Hitchcock, Susan Tyler (2010). Frankenstein: as muitas faces de um monstro (Trans. Henrique Amat Rêgo Monteiro). São Paulo: Larousse do Brasil.

[6] Jones, Stephen (1994). The Illustrated Frankenstein Movie Guide. London: Titan Books.

[7] Lyons, Sherrie L. (2009), Species, Serpents, Spirits, and Skulls: Science at the Margins in the Victorian Age.

[8] Mellor, Anne Kostelanetz (1988). Mary Shelley, Her Life, Her Fiction, Her Monsters. London: Routledge.

[9] Montani, Pietro (1999). L'immaginazione narrativa: Il raconto del cinema oltre i confini dello spazio letterario. $2^{\text {a }}$ ed., Milão: Guerini e Associat Albany: New York Press.

[10] Parens, Erik (2000), Enhancing Human Traits: Ethical and Social Implications. Georgetown University Press.

[11] Shelley, Mary (1869). Frankenstein or Modern Prometheus. Cambridge: Sever, Francis \& Co

[12] "A list of Movies based on Frankstein, 1910-2005" (2009), In Stuart Curran (Ed.), Romantic Circles Electronic Edition. Retrieved from: www.rc.umd.edu"https://www.re.umd.edu/ editions/Frankenstein/Pop/movies" 
[13] Zizek, Slavoj (2006), A Subjectividade por Vir - Ensaios Críticos sobre a Voz Obscena. Lisboa: Relógio D’Água Editores. 